\title{
AFFECTIVE ATMOSPHERES OF TERROR ON THE MEXICO-U.S. BORDER: Rumors of Violence in Reynosa's Prostitution Zone
}

\author{
SARAH LUNA \\ Davidson College \\ (D) http:/ / orcid.org/0000-0002-2278-1114
}

In Mexico City in January 2011, I organized a reunion with Eva and Sofía, whom I had become close to during my twelve months of fieldwork in Reynosa's prostitution zone - known locally as la zona or as Boystown among many Americans. ${ }^{1}$ When I met Eva and Sofía, they both expressed that they urgently needed to leave Reynosa. They feared for their lives because gun battles and techniques of intimidation by armed men had increased since federal troops had been sent to Reynosa to combat drug trafficking. They were barely able to make a living as sex workers because the economic crisis, the swine flu, and drug violence had scared clients away. Eva, who was in her fifties, had escaped El Salvador's civil war after many of her family members had been killed. She moved to Reynosa to work in la zona to support her daughters and grandchildren in central Mexico. Sofía, a single mother in her thirties, worked to send money to family members in her hometown of Tampico who were caring for her adolescent son, Sergio, whom she eventually learned was working for a drug organization. ${ }^{2}$

Sergio and his pregnant fourteen-year-old girlfriend joined my reunion with Eva and Sofía in Mexico City in 2011. The five of us slept in a large hotel room for three days and ate meals, took photos, and walked through Chapultepec Park together. We exchanged news and gossip, reminisced about funny things that had 
happened, and repeated rumors of the gun battles and murders that took place in Reynosa. Sergio and Eva compared observations about the techniques of intimidation that drug organizations used in Mexico to the practices Eva had witnessed during El Salvador's civil war. They told stories of watching their friends and family members being killed. They described the red color bullets leave in their wake as they pass by, and their hot sting when they enter the body.

One morning, as we were all eating a breakfast of orange juice, coffee, and spicy egg dishes, the narco-stories of the day began. Although we were ostensibly a safe distance from Reynosa's narcos, in hushed tones, Eva told us a story about two "little old women" shopping at a market in downtown Reynosa. While one woman loudly recounted a rumor about narcos, the other remained quiet and looked nervous. The loud woman was later found dead, with a severed finger in her mouth. A note was attached to the corpse: "Keep quiet if you don't have anything to say." Our eyes widened, we breathed deeply, and we looked at one another in silence.

Rumors like the one Eva narrated have shaped affective atmospheres of terror, especially as Reynosa has become further militarized by the Mexican state in what was officially an attempt to combat narco-trafficking and its attendant torture, killings, and threats. ${ }^{3}$ As Reynosa residents spread rumors of violence, borders between narco-controlled territory and state-controlled territory shifted in and through their bodies. I argue that, in such atmospheres of terror, rumors of violence have a particular kind of contagious performativity that conditions affective responses and inculcates both fear and intimacy. These stories produce shared bodily intensities such as a rapid heart rate, a slowness of breath, and a hyperawareness. In the first part of this essay, I draw on theories of performativity, conspiracy, and affect to analyze the rumor Eva told us. The circulation of such stories constructed affective atmospheres of terror and intensified feelings of vulnerability. The second part of my discussion examines how Reynosa residents generally, and sex workers specifically, changed their spatial practices in response to both affective atmospheres of terror and the content of rumors. These effects first occurred among Reynosa's less empowered populations, such as sex workers, and eventually among populations that historically felt relatively safe in border cities, such as American (sex) tourists and missionaries. I conclude with how this particular manifestation of fear and precarity led to the decline of the prostitution zone for sex workers, missionaries, and clients.

Performative rumors of violence shape the way power feels. The primary forms of power held by drug organizations that I discuss here are tied to coercion 
grounded in violence - the power to kill or let live - as well as in the economic ability to purchase loyalty and impunity. This kind of power is best described by the expression plata o plomo, silver or lead, which is the choice narcos offer between accepting currency (in exchange for cooperation) or a bullet (death). Plata o plomo is a key method through which drug organizations have woven themselves into Mexico's political fabric. Howard Campbell $(2009,16)$ shows how plata o plomo has proven integral to relationships of "corruption and collusion" between drug traffickers and Mexican police, as well as judicial and military forces. ${ }^{4}$ Because narco power and state power overlap at various levels, they are often indistinguishable to the populations that reside in their territories. Fear forms an important part of the power wielded by drug organizations, which have diversified economic strategies to include protection rackets, extortion, and kidnapping. The spread of terror makes their other enterprises profitable (see Campbell and Hansen 2014). While drug organizations clearly take part in actions meant to spread fear, this article focuses on how practices of the resident population likewise contribute to atmospheres of terror.

My analysis adds to a growing body of literature that demonstrates how the most vulnerable populations suffer the consequences of a war on crime. After a contested win in December 2006, President Felipe Calderón deployed fifty thousand troops throughout Mexico in the name of public safety. Calderón's critics accused him of using the drug war to legitimize his unpopular presidency. During Mexico's drug war, partially funded by the United States through the Mérida Initiative, tensions between drug organizations and armed men of the state increased, ${ }^{5}$ gun battles became more frequent, the murder rate nearly tripled, ${ }^{6}$ and people felt less and less safe. Of course, Mexico's problems with drug violence are of binational origin. The United States is in great part responsible for the ascendance of Mexican drug organizations through interventions into Colombian drug-supply routes, the smuggling of firearms to Mexico, the purchase of Mexican drugs, and the implementation of prohibitionist and neoliberal policies (Andreas 1995, 1996; Campbell 2009; McDonald 2005; Muehlmann 2014). The militarization of both sides of the border has escalated wars on drugs, terrorism, and organized crime, rendering life more dangerous for both countries' most vulnerable populations (Campbell 2009; McDonald 2005; Muehlmann 2014; Vite Pérez 2014). Working in the narco-economy is one of the few options for young men in many parts of Mexico where poverty, unemployment, and underemployment have increased since small and medium-sized farmers were bankrupted through NAFTA and agrarian reforms (McDonald 2005). 


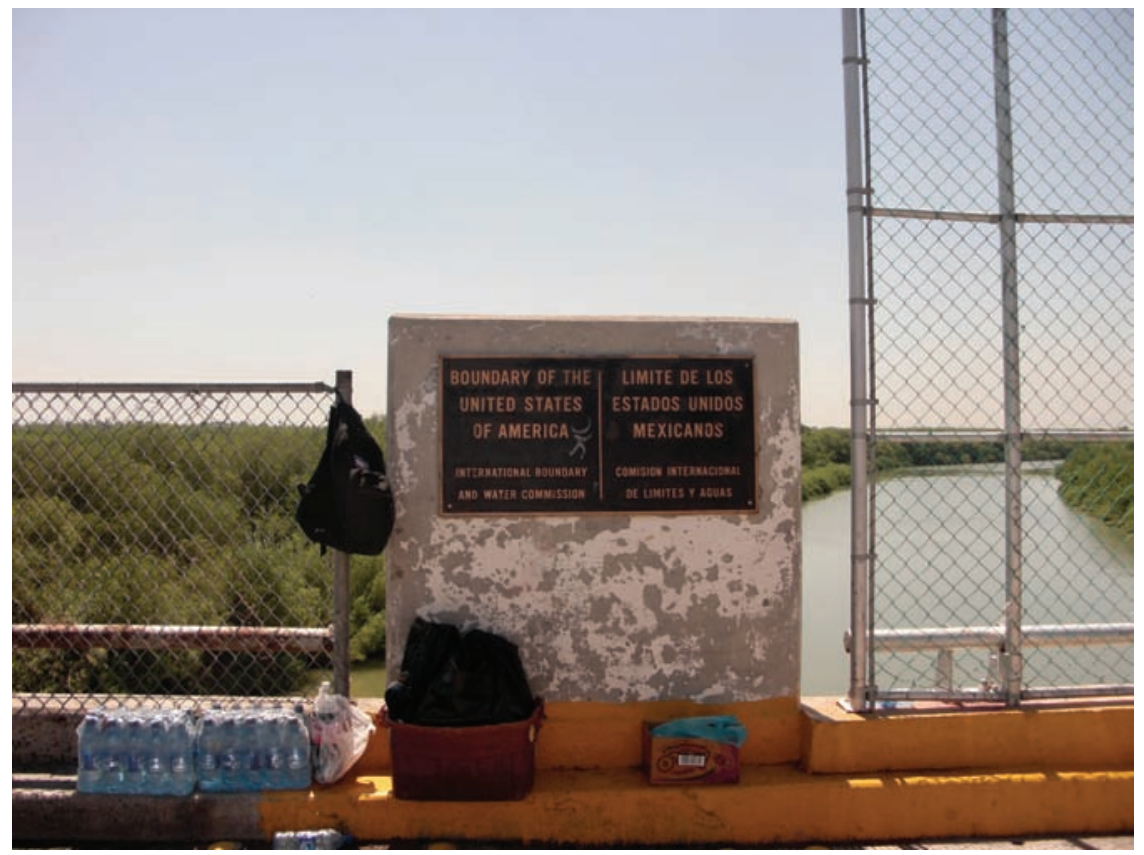

Figure 1. The McAllen-Hidalgo-Reynosa International Bridge. Photo by Sarah Luna.

Tamaulipas is one of the key sites for the northbound smuggling of cocaine, marijuana, and migrants, as well as the southbound smuggling of guns (made easier by lax Texas gun laws) and U.S. dollars. It is also the home of the Gulf Cartel, one of Mexico's oldest drug organizations, which began smuggling alcohol and other items to the United States during the Prohibition era. Drug organizations are deeply embedded in the social life of Reynosa, and almost everyone I met from Reynosa had worked for or with narcos in some capacity, whether voluntarily or not, including teachers, police officers, dentists, graphic designers, and taxi drivers. Reynosenses noted that narcos had long run their city, often in collusion with local law enforcement and politicians. Although Reynosa was far from peaceful before, Reynosa residents experienced heightened fear and bloodshed after soldiers and federal police flooded Reynosa's streets in December 2007.

I met both Eva and Sofía in 2008 through a white missionary, Stacy, who moved to Reynosa from Tulsa to form a small mission team when God told her to "love the women of Boystown." Sex workers and missionaries met in Reynosa's prostitution zone, which is surrounded by cement walls, with only one principal exit and entrance guarded by municipal police officers who collect money and provide security for clients and workers. Because the security guards 
did not let her into Boystown, Stacy prayed and walked around the periphery for fifteen months until her friendship with a drug dealer and pimp facilitated her entrance. Prostitution in Reynosa is legally tolerated if sex workers register with the city and are examined for sexually transmitted infections by the city's health department. La zona was considered to be the territory of the drug organization in power, and high-ranking narcos were said to be the owners of many of the buildings within the walled enclosure. La zona was theirs, much as the city of Reynosa was: through bribes, threats, and inciting general fear. Narcos ran their business as they pleased and demanded compliance from residents.

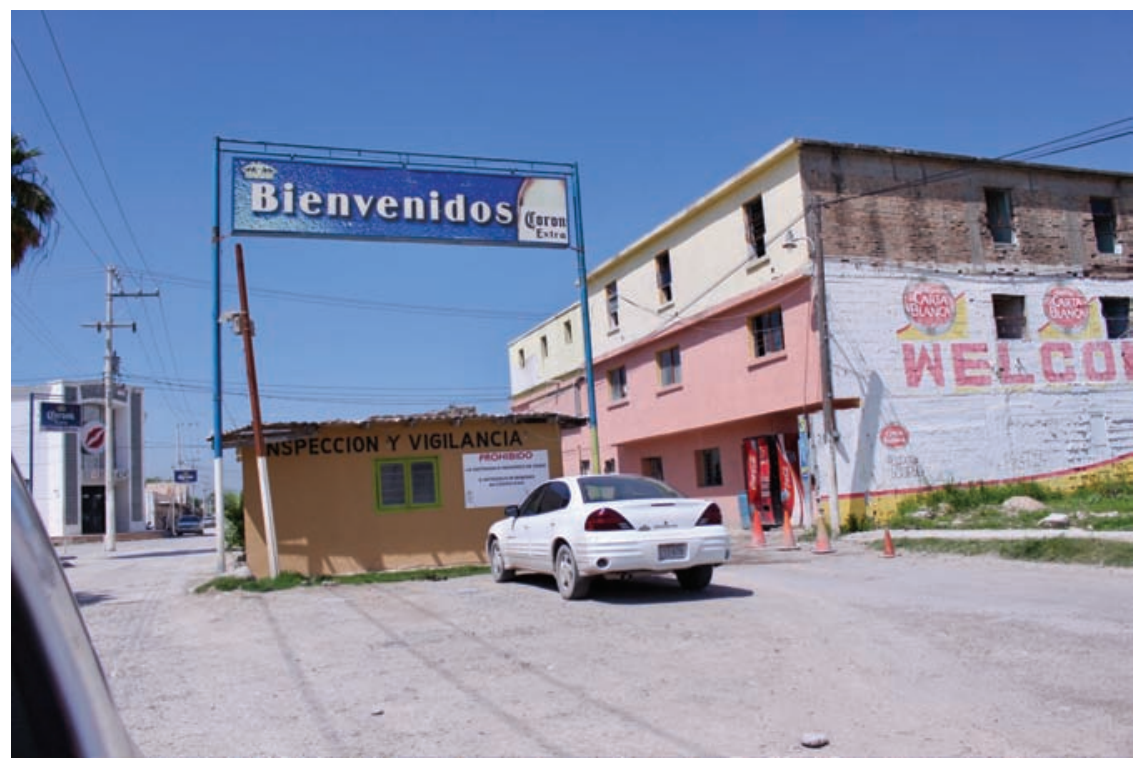

Figure 2. The entrance to la zona. Photo by Sarah Luna.

Boystown vividly reflected economic inequalities between the United States and Mexico, and it also provided an opportunity for women to leverage those inequalities into monetary resources that they could use to support themselves and their families. American sex tourism historically helped make Mexican border prostitution zones profitable (see Curtis and Arreola 1991), and many sex workers migrated to Reynosa hoping to earn dollars. Most were single mothers whose work was motivated by relations of love and obligation to children, parents, and/ or pimps. ${ }^{8}$ Sex workers' temporary intimacies with clients earned them cash that they could convert into subsistence, commodities, and savings that they hoped would lead to economic stability for themselves and their families. For their part, 
missionaries explained that because Jesus chose to spend his time with "poor and forgotten" people like prostitutes, getting to know sex workers made them feel closer to God. Stacy and her team built friendships with sex workers, prayed for them, and learned their names and stories. They also circulated sex workers' narratives to Christian congregations and blog followers who supported the mission through prayer, money, and short-term teams who worked to build what they called a "modern-day monastery." Missionaries had faith that their relationships with sex workers would lead to relationships between sex workers and God, which would in turn result in sex workers leaving Boystown and quitting sex work. Thus Boystown enabled the creation and maintenance of relationships both within and beyond its parameters. However, factors from 2008 to 2010 led many missionaries and sex workers to leave Reynosa. The atmosphere of terror effectively destroyed some of the ways in which migrants created intimate ties and fulfilled obligations.

\section{CONTAGIOUS RUMORS AND BODILY INTENSITIES}

All of us having breakfast that day in Mexico City, recalling times both good and bad, first felt Eva's story about the old woman with a finger in her mouth on an affective level. Affects are intense sensations in the body resulting from external stimuli, and they are noncognitive, nonconscious, and nonrational (Gould 2009, 19-20). Rumors shape emotions, actions, thoughts, and subjectivities, but they are first experienced at the level of affect. ${ }^{10}$ While emotions are largely individual, affect is intersubjective and bodily transmitted, and, as Sara Ahmed (2010, 39) notes, “contagious” (see also Richard and Rudnyckyj 2009; Herrmann 2015). "Ordinary affects," as Kathleen Stewart (2007, 2-3), has written, "are public feelings. . . . Their significance lies in the intensities they build and in what thoughts and feelings they make possible.” My bodily response during Eva's story was a fight-or-flight adrenaline surge and a rapid heartbeat. In an attentive state of increased psychological and physiological tension, I breathed slowly and leaned in to hear Eva's whisper. Surely these affective intensities were experienced in different ways by different people. As Lauren Berlant $(2008,4)$ notes, the emotional states linked to affective structures are not predetermined. Rumors help shape an affective atmosphere, which Ben Anderson (2009, 78) defines as "the shared ground from which subjective states and their attendant feelings and emotions emerge."

Stories of narcos' exploits were followed by long moments of silence and intense eye contact; sometimes there were tears. Eva broke the heavy silence by 
affirming for us all: "That is why I need to leave Reynosa." When I asked her if she could think of any kind of solution to what was happening in Mexico, Eva said that all we could do was pray, and she assured me that God must have kept her alive for a reason. Although living in territory contested between drug organizations and state actors put Eva at risk, she ultimately had faith, or hope, that God's sovereignty would prevail.

While designating a narrative as a rumor or a conspiracy theory calls into question its truth-value, this is not my intention. ${ }^{11}$ My analysis of rumors, rather, is in line with that of scholars of conspiracy theory who do not attempt to assess the veracity of narratives but rather examine them to make sense of particular political conditions in which available information is incomplete or inconsistent (Fenster 1999; Keeley 1999; Stewart 1999; Butt 2005). Stories like the one told by Eva proved vital for transmitting information to one's friends and family, in part because people associated with drug organizations effectively controlled the press. While I knew as early as 2008 that the press was not free in Reynosa (and Reynosenses knew this long before I did), this information circulated only in rumors until surfacing in the U.S. and Mexican press in 2010. That year, Mexico was the second-deadliest country in the world for journalists (Heslop 2011), and during a two-week period, eight journalists in Reynosa were kidnapped; two were released with a warning, one died after being tortured, and four are still missing (Stevenson 2010; Pérez Arellano 2013). Many gun battles in Reynosa went unreported by the local media, ${ }^{12}$ so people depended on rumors for information.

Rumors and conspiracy theories can operate as critiques of larger power structures by people with little access to power (White 1997; Masquelier 2000; Comaroff and Comaroff 2001; Hoskins 2002; Kirsch 2002). Rumors are one means through which people react to collective experiences of inequality, exploitation, and political violence, and the circulation of rumors intensifies during times of extreme exploitation and suffering (White 1997; Masquelier 2000; Kirsch 2002; Butt 2005). The violence and inequality in the neoliberal and heavily militarized Reynosa of 2008 and 2009 created fertile ground for rumors. Claudio Lomnitz-Adler (1995, 36) suggests that Mexicans have relied more heavily on gossip than on official information sources because the national public sphere has rendered itself untrustworthy by excluding many voices due to power asymmetries. Rihan Yeh (2012) further demonstrates asymmetries in the Mexican public sphere through her analysis of Tijuana's two publics: one constituted by the lower classes through hearsay, while the bourgeois-type public rested on a "we" of 
citizenship that distanced itself from poverty and criminality. Reynosenses who considered themselves locals constituted a bourgeois-type public. In private Reynosenses whispered complaints that narcos were taking over their city, and in public they loudly complained about migrants from southern Mexico and Central America, attributing the city's problems to them. For the purposes of my discussion, I have focused on what Yeh $(2012,716)$ would call the "hearsay public" register.

During the drug war, rumors of violence had performative effects - their contagion circulated affectively and increased perceptions of risk and vulnerability. Performative rumors played an important role in constituting power relations they might, at first glance, appear only to describe. I am thus interested in what kind of work local theories about power in Reynosa do. Rumors are performative speech acts in the sense theorized by J. L. Austin (1962), utterances that do not merely describe but also accomplish something in the social world. ${ }^{13}$ These rumors had corporeal and social effects, creating intense sensations in bodies that led not only to collective fear but also to shared intimacy.

Performatives cannot be evaluated in terms of truth, because their success requires felicitous conditions that allow them to do the things in the social world that they name. I do not know if an elderly woman was found with a severed finger in her mouth. The local press in Reynosa did not publish such things. The absence of a free press and the fact that people periodically received evidence of violent acts created the conditions of possibility for such rumors to be especially poignant. Howard Campbell $(2014,64)$ shows how narco-propaganda has propagated terror in Mexico through public acts of violence, media censorship, and written statements, videos, and music. Reynosa residents were active consumers of narco-propaganda, including my host family, which crowded around a computer to watch videos of Reynosa's gun battles. Some were filmed by news reporters while others were taken on cell phones and put to the soundtrack of narcocorridos, ballads about drug trafficking. One of my host sister's friends, Josiah, claimed that the song "Fiesta en la sierra," by the musical group Tucanes de Tijuana, was an accurate reflection of the ties between narcos and politicians. The song is set at a lavish ranch party in the mountains where Mexican politicians and high-level narcos socialize together. Invoking the "we" of the Gulf Cartel and referring to the mayor of Reynosa, Josiah said, "We put him into power." Politicians were elected as well as killed to the beat of narcocorridos. When Juan Antonio Guarjardo Anzaldúa, Rio Bravo's ex-mayor running for re-election, was gunned down with five other people in broad daylight in November 2007 (Sánchez 
et al. 2007), the Tucanes de Tijuana allegedly played at a party put on by a drug organization to celebrate his death at Reynosa's Holiday Inn.

The circulation of rumors, threats, and the occasional display of dead, mutilated bodies, sometimes with messages attached, generated a public both passive and terrified. Iterability is partially responsible for the power of narco-stories. Jacques Derrida (1982) argues that part of what makes performativity work is the ability to cite previous instantiations. Drawing on both Derrida and Austin, Judith Butler (1990) argues that a gendered subject does not exist a priori but through the enactment of gender, creating the illusion of an already gendered subject. In Reynosa, the circulation of rumors of violence led to affects embodied in emotions such as fear and anxiety that changed the way people experienced their own vulnerability. Rumors form an important part of discursive power; their presence changes how people talk and think about the world and imagine their place in it. As we will see below, vulnerability was gendered, raced, and classed, but the circulation of narco-stories contributed to atmospheres of terror that created increasingly vulnerable-feeling subjects all around. The repetition of violent narco-stories not only expressed cartel power but also amplified it. According to Danilyn Rutherford (2012, 101), every violent act may be considered performative insofar as it "says" what it "does." I argue that, in environments of terror, even rumors of violence are performative in this way. Narratives about incidents of assault, kidnapping, torture, and murder do not say what they do in the same way that experiencing or witnessing violence does. Yet while rumors may not create the physical violence they name, I have found that they have performative effects, producing a sensation akin to what subjugation feels like. Narco-stories produce the anticipation of pain just as they produced the terror of the apparently unchecked power of narcos.

All rumors, like all speech acts, have performative capacities. Rumors of violence differ in that they recapitulate previous violent acts and contagiously shape how power feels for the people circulating and listening to these stories. As in Derrida's conception of iterability, some rumors have been circulated so many times and in so many contexts that they have become spatially, temporally, and substantively separated from original acts of brutality. Some narco-stories surely named events that never occurred, but Reynosenses witnessed violent acts often enough to sustain belief in rumors. Yet despite, or perhaps because of, the distance between the violent act and its performative citing, rumors continue to draw on the power of violent acts. As with Michael Taussig's (1986) concept of epistemic murk, what happens in the imagination adds force to the power of fear 
in an environment of terror. These gaps between the evidence of violent acts and perceived violence not only intensify fear but can also, perhaps oddly, allow rumors to provide a feeling of comfort, because they help make sense of an uncertain world. But these rumors lull their circulators into a false sense of security. As Stuart Kirsch (2002, 70, 57) writes, "Much as violence often begets violence, rumours about political violence seem to reproduce rather than critique existing power relations." Thus rumors about political violence are both an expression and a source of terror.

Sharing rumors about torture, murder, and kidnapping produced affective states that allowed for the bond of collective trauma in Reynosa. Stranded in a mutual sense of powerlessness and isolation, migrants withheld information from faraway family members to avoid worrying them and nurtured local intimacies, in part, through the circulation of narco-stories. Missionaries, sex workers, and I observed that when we traveled to other cities to visit family members, it was difficult to explain how fear haunted us in Reynosa. Indeed, many of us lied to loved ones so as not to worry them.

Rumors of violence in an atmosphere of terror are contagious in part because they help sustain social bonds. Sex workers would often preface a story about narcos with, "I may end up floating in the river for telling you this, but . . ." The "but" was followed by the revelation of a rumor. They divulged stories and speculations compulsively, torn between reluctance and recklessness, and they often spoke in whispers, a gesture reflecting both the regulation of fear and the intimacy of trust. These moments of sharing created intimacy in an uncertain world. The take-home message of the narco-story about a gossiping old woman who was found dead with her finger in her mouth was that one should not speak of narcos in public, yet people like Eva spread these stories regardless of risk. They served as a parable-like warning to those with loose lips.

Given the potential risks of exchanging rumors, the latter not only created but also reflected trust and intimacy. When I asked my closest contacts to repeat these stories for my recorder, they did so hesitantly, tensely, and with fewer details. I suspected, but never asked to confirm, that we feared the same fate: that a high-ranking narco would find my recording and torture and murder the participants of my study or me. ${ }^{14}$ I could never tell if this was a reasonable fear or paranoia.

Reynosa residents cared for one another through text messages, phone calls, Twitter, and Facebook. On social media, I observed Reynosa contacts warn each other of where they heard gunshots or explosions. Spreading rumors despite the 
risk constitutes an act of care because disseminating knowledge can, in theory, keep those who acquire it safe from harm. These rumors often have a warning subtext: Don't honk your car horn. Don't leave the house at night. Yet circulating narco-stories was not only a means of caring for one's loved ones; it also worked, on an affective level, to spread terror.

\section{EMBODIED SPACES OF NARCO/STATE TERRITORY}

Affective atmospheres of terror had embodied, spatialized, and social effects that changed how people moved through Reynosa generally, and through la zona specifically. Setha Low's (2016) concept of embodied space pays attention to the human body as a spatial field that both constitutes and shapes space. Low's work not only bridges smaller-scale analyses of bodies and macro-analyses of the social and political world but also supplements accounts of the material production and phenomenological construction of space with bodies and their affects, mobilities, and feelings. This concept helps explain how terror contagiously spread through bodies in specific kinds of places and altered peoples' trajectories, which in turn had material and social effects on border cities as businesses closed and migrants returned to their places of origin. Fear pervaded the embodied habits of whispering rumors, scanning the landscape for new SUVs, and driving carefully. Narco-stories generated temporal and spatial topographies of fear in Reynosa that eventually became generalized to any time and place. As shootings, which had historically occurred at night, started to happen during the day, many Reynosenses became reluctant to leave their houses at all during particularly violent periods.

Affective atmospheres of terror were spatialized, as were the places of intimacy where people disclosed rumors about violence. Particular locations became infused with terror when people heard gunshots or revealed narco-stories. Sex workers would not tell me certain rumors of cartel activity in coffee shops or restaurants, fearing that the space might be bugged or that we might be overheard by a high-ranking narco. They waited until we were in my car or their rooms to tell me the rumors that scared them the most. Even in periods of heightened fear, though, places such as my car, sex workers' rooms, and missionaries' houses remained filled with stories other than narco-stories and affects other than terror. Sex workers gossiped about each other, missionaries spoke about their families, and we planned a missionary's bachelorette party. In Reynosa, I observed and participated more frequently than in other periods of my life in laughter so intense it caused crying, bellyaches, and difficulty breathing. These bodily intensities were likely the flip side to our terror. 
Reynosa residents altered their spatial practices in relation to the content of rumors. Rumors of further violence kept the streets empty for days after a threehour public gun battle between soldiers and members of drug organizations had shot up a school while children hid under their desks to dodge bullets (Crónica de Hoy 2009). My host mother worked at a preschool that was closed due to bomb threats. She and my host sisters stayed in the house for days, complaining about their boredom on social media. But fear of the street extended beyond the fear of dying in a gun battle. This story was first told to me in whispers at a fiftieth birthday party in McAllen, Texas by a man who, like many of us at the party, lived across the border in Reynosa, Tamaulipas.

A woman in a car sat waiting at a traffic light for several minutes after it had turned green because a brand new Lincoln Navigator with tinted windows and U.S. plates was idling in front of her. She didn't honk her horn. Finally, a man got out of the car and approached her, laughing. "My friend and I had a bet," he said. "I told him that if you honked, I was going to kill you, and if you didn't honk, I was going to give you five hundred pesos." Opening his jacket to expose his gun, he handed money to her and said, "You win."

My host mother later forwarded me an email of the first-person account of the same story, which ended in a warning to the loved ones of the narrator to exercise caution and to avoid honking their car horns. This story was told to me as an act of care to help me safely navigate the city by car. But these rumors also summoned fear at the moment of telling that would resurface as I drove around the city.

Although this story rehearses plata o plomo, its protagonist was not granted the opportunity to choose between silver and lead; she was a pawn in a deadly game she did not know she was playing. In this rumor plata o plomo appears, at first glance, to be a mere game for narcos' amusement rather than a political/ economic strategy. Yet the fear generated by the rumors that snowball from such (possible) acts reinforce their political and economic power. The takeaway of this rumor, like many circulating in Reynosa at the time, was that one should be vigilant and treat narcos with respect and deference.

Narcos' imagined omnipresence had a disciplining effect. Drivers in Reynosa were especially aware of their behavior around new, luxury-brand SUVs with tinted windows. As anyone could be a narco, attentiveness to visual and spatial cues prompted anxiety. The circulation of narco-stories spread awareness of cor- 
poreal vulnerability and instilled habits of self-surveillance and behavioral restraint thought to mitigate danger. Many people avoided honking at stopped cars and exchanged tips for negotiating interactions with armed men who might pull them over while in traffic, which also fueled terror. None of the sex workers I knew had cars, but even on foot, they found it ever more stressful to navigate the city and so became reluctant to leave Boystown, where they felt safer. While money and violence provided the material grounds for narco power, the contagion of rumors spread terror in ways that caused people to alter their spatial practices.

People in northern Mexico during this era particularly associated Reynosa with drug activity and bloodshed. Young men from Reynosa told me that when they traveled to Monterrey (which would, several years later, become as violent as Reynosa), people there assumed that most Reynosenses had narco ties. Those of us who lived in Reynosa shared the perception that it was more dangerous than other cities where we spent time. When I left town with sex workers or missionaries, we often felt a sense of relief, like we could breathe. While affective atmospheres become mapped onto space, it is through the space of bodies that they travel and live. Some of this terror lingers in bodies even as they travel to different locations, since affect shapes subjectivity and habitus.

As tensions between state actors and members of drug organizations escalated, sex workers felt increasingly vulnerable to narcos in la zona. Once, when I was standing in front of Eva's room during a moment of downtime, she whispered to me:

We [the sex workers] are in danger here [in the prostitution zone]. Everyone is in danger, but we are especially in danger here. La maña [a term at the time used interchangeably with narcos] comes every week to take money from us, and if we do not pay it, they write it down, and they will beat us or kill us if we do not pay. I could end up dead, floating in the canal, and my children wouldn't even know what happened to me, because they don't know what I do for a living. They would just know I disappeared one day.

Eva's sense of risk was tied to her obligation to provide for her children and grandchildren and to her desire to protect them from news of her death. Migrant sex workers' vulnerability was structured by their stigmatized professions and their visibility in la zona, as well as by the way in which the preexisting apparatus for their control by the state was co-opted by a drug organization. 


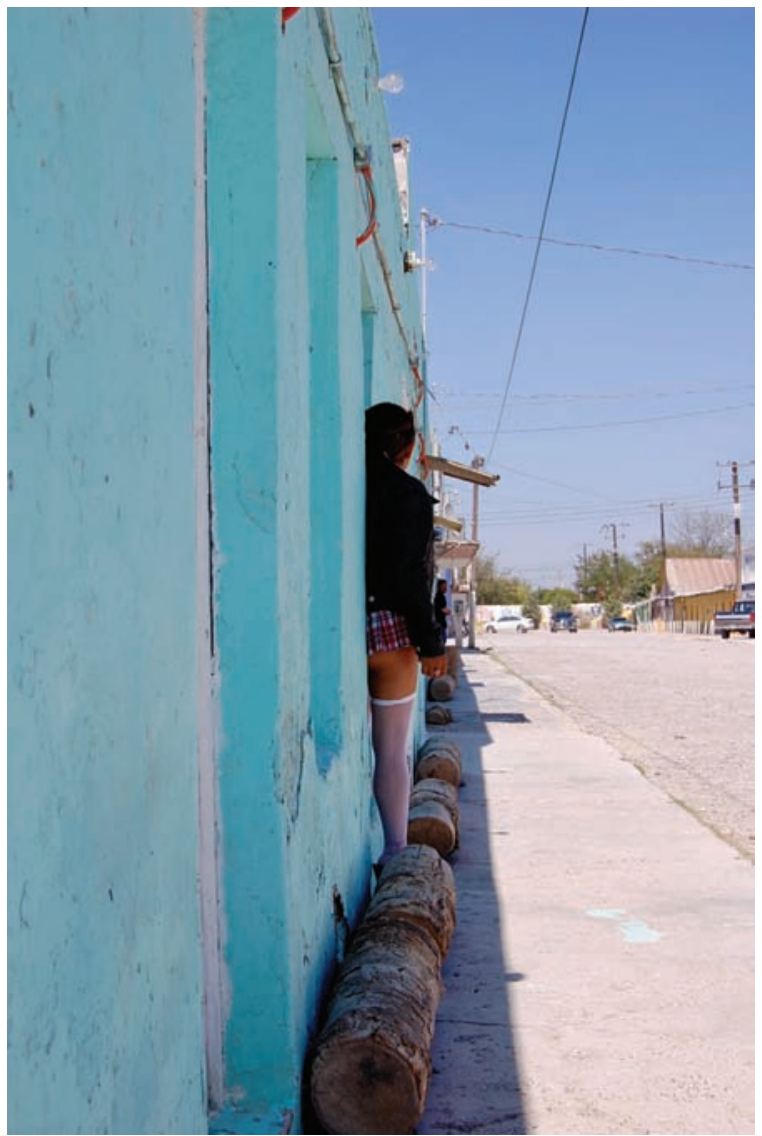

Figure 3. A sex worker in front of her room in la zona. Photo by Sarah Luna.

Sex workers occupied a gender, race, and class position that shaped their vulnerability. On the Mexico-U.S. border, as in many other places, if a woman is taken to be a "whore" (sexually promiscuous or an actual sex worker), she can be blamed for her rape or murder. As Melissa W. Wright (1999, 2011) notes, local discourses in Ciudad Juárez surrounding the rape, mutilation, and murder of working-class women blamed the victims, suggesting that if they were alone on the street at night, they must have been prostitutes. That the Ciudad Juárez femicide victims did not, in fact, perform sex work demonstrates the larger social implications of the whore stigma that, as Anne McClintock (1992, 3) notes, is used to discipline all women. But this discipline is unevenly applied to people who are racially marked, poor, and gender-nonconforming. I was sometimes mistaken for a sex worker, while at other times I was taken for a missionary. I 
felt safer when I was surrounded by white, English-speaking missionaries than if I was with other Mexican friends, including sex workers. My perception of my vulnerability shifted depending on my company, because I was aware of the relative impunity surrounding the murder of poor brown women in border cities. Fewer rumors circulated of violence toward American citizens, which was more likely to generate international news. Perhaps affective atmospheres differ based on the color, citizenship, gender, and class of the bodies that constitute them, as these factors shape these bodies' relationship to power and disposability.

During breakfast one morning in Mexico City, Eva told Sofía and me about the closure of Baile, a dance club we had all visited in Reynosa. Internal migrants from Veracruz who worked low-wage jobs frequented Baile, where men paid women the equivalent of a dollar to dance with them. Sofía and her friends occasionally danced at this salon to earn money and solicit clients. Eva told us Baile closed because a room full of freezers was found stuffed with corpses missing vital organs. "They say most of the victims were veracruzanas," she said, "and la maña sells their organs to Americans and rich people in Mexico.” More than just a gruesome piece of gossip, Eva's story expressed anxiety about the vulnerability of poor, racialized bodies marked with the whore stigma in relation to narco power and predatory U.S. capital. In Reynosa, racializing discourses described veracruzanos as lazy, promiscuous, and polluting the city.

In 2008, I started to hear rumors that Central American migrants on their way to, or just deported from, the United States were being found in mass graves, following their kidnapping, torture, and the extortion of their families. I began to see newspaper coverage in $2010 .^{15}$ Eventually, Mexicans started to fear that they would disappear like Central Americans. On the so-called Highway of Death in 2010 and 2011, Mexican citizens were among those forced to exit buses; some were raped, and most were never seen again (Ramsey 2011; Torres 2011). Thus, as mass graves full of bodies were eventually assumed to also include Mexicans, tensions rose as people previously granted security worried that they would meet the same fate. As the contagion of terror spread, the differences that once separated more from less vulnerable bodies gradually faded.

In stories like the one narrated by Eva, narco power emerges with few constraints, as almost absolute and God-like. Stories of narcos threatening, killing, and mutilating people as well as controlling various aspects of political life snowballed through rumors, in effect magnifying the power of drug organizations. Whether or not narco-stories accurately reflected the social world, each rumor's circulation constituted a further iteration of this power. The subject in most of 
these rumors, the agentive actor in each sentence, was a supposed narco; the verb was torture or murder; the direct object was a person that the speaker and listener were afraid they might become. Consequently, each telling and retelling of a narco-story spread both imagined and felt narco power and created subjects regulated through fear.

Shortly after federal troops were sent into Reynosa in December 2007, every business selling alcohol, including in la zona, was given orders to close at 10 p.m. and remain closed until 10 a.m. Newspapers speculated that these were military orders. However, a city-level public official in Reynosa in charge of media relations stated that neither the city government nor the state or federal authorities had imposed the curfew (Osborn 2008). Reynosa residents believed la maña put the curfew into place. In one common explanation, narcos attempted to limit the local economy to mobilize local resistance to the military occupation. During this period, many people in Reynosa took extra care to remain inside at night because they heard rumors that those on the street after 10 p.m. would be shot.

A march against narco violence in August 2008 in Mexico City included hundreds of thousands of people, and this was only one of many marches throughout the country. Yet no such march against narcos occurred in Reynosa, and locals noted that Reynosa residents would never organize an anti-narco protest due to either apathy or fear. Although they did not protest against narcos, Reynosenses did protest the military presence in Reynosa in early 2008 and early 2009. One march included a thousand people, mostly those involved in the nighttime tourist industries such as bar, restaurant, and club owners, waiters, sex workers, taxi drivers, and mariachis (Proceso 2008). The protesters accused the military of human-rights abuses and demanded they leave Reynosa. Yet many locals told me that the protests were not organized by concerned citizens, but rather by narcos. ${ }^{16}$ A woman living in a squatter area in Reynosa who had protested told me that la maña offered her and her neighbors bags of food and money to pile into buses and protest. ${ }^{17}$

Territory battles between narcos and soldiers became enacted via the bodies of sex workers. A week before one of the marches, men who appeared to be soldiers blocked the exit and entrance of la zona with what seemed to be military vehicles. Toting guns, they assaulted sex workers and clients. In retrospect, sex workers speculated that la maña had committed these acts of intimidation and violence dressed as soldiers so that they would want to join the protest against the military. Several days later, a man wearing a ski mask who identified himself as part of la maña told sex workers that they must join the protest or else lose 
the right to work and be punished with spankings on bare buttocks with a large wooden paddle. These spankings, tablazos, constituted a punishment that formed part of an alternative justice system for offenses that would not warrant torture or murder. Sofía told me that narcos visited jails to give tablazos to everyone accused of either rape or beating women or children "before they [were] sentenced by the law." When Eva was sick and unable to march, someone from la maña threatened to give tablazos to her good friend Sofía, who had been made responsible for making sure that all her colleagues marched. Eva and Sofía lived on the same block in Boystown, often ate meals together, and would watch each other's rooms when the other left town to visit family. By assigning responsibility to one woman, narcos used established intimacies to create cooperation. Once Sofía left la zona to return to Tampico, Eva was given responsibilities originally assigned to Sofía, and she risked punishment if other sex workers did not comply with orders.

Sex workers' bodies proved particularly vulnerable in confrontations between narcos and soldiers. "They put us at the front lines." Sofía explained. "If someone was going to die in that situation, it would have been us." That sex workers were threatened with physical force and economic sanctions instead of bribed with money indicates that la maña possessed a kind of power over sex workers that they did not have over some other Reynosa residents.

According to local narratives, narcos both masqueraded as state actorsdressing as military officials - and acted as civil society: organizing protests and using both gifts and violence to coerce people to participate. Whatever the truthvalue of these reports, the attribution of these roles to narcos implies their power to generate fear and compliance. In militarized Reynosa, narcos were given credit via rumors for almost all acts of violence and politics. That protests were believed to be fueled by narco threats and bribes compellingly reflects on how people imagined power to work in Reynosa. Following the militarization of state interventions at the border, the intensification of cartel power resulted in the breakdown of institutional and political differentiation in the minds of the public. In response, the public engaged in a range of communicative and interpretive practices such as telling each other stories of brutality and tweeting about locations of gun battles, practices that sustained interpersonal social obligations under circumstances of extreme anxiety and risk. Ironically, the same narco-stories that manifested cartel power in the public sphere also provided border residents a private space in which to foster intimate ties and practice care. 


\section{INTENSIFIED VULNERABILITIES AND BLOCKED INTIMACIES IN}

\section{LA ZONA}

The factors that made Reynosa a popular destination for foreign visitors like sex tourists and missionaries were overshadowed by fear of drug organizations' activities. Depictions of narco violence in the U.S. media, another kind of rumor that spreads terror, proliferated from 2008 to 2010, ${ }^{18}$ and American citizens I interviewed reported feeling less secure in Mexican border cities. While tourism had already seen a decline, media coverage of the violence in Mexico had a significant impact on Reynosa, where revenues dropped by half in 2010, following already important reductions in 2008 and 2009. Tourism dropped 40 percent in Tamaulipas between 2009 and 2010, and thirty-eight restaurants in Reynosa closed that year (Milenio 2010). Residents' responses to fear were structured by inequalities of mobility. The privilege of leaving Reynosa for safer places was accessible to Americans (including missionaries and anthropologists) and Mexicans with visas or savings. Most sex workers, like other low-earning workers in the informal economy, left Reynosa only to return to hometowns similarly inundated by fear and bloodshed.

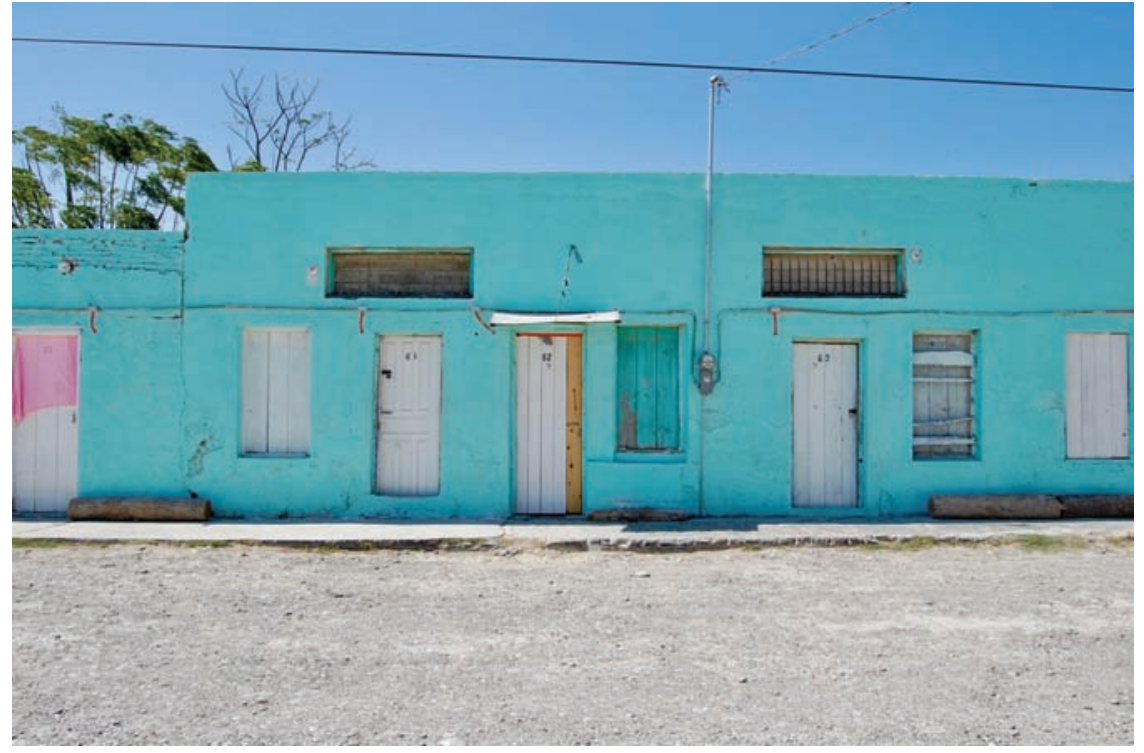

Figure 4. Sex workers' rooms in la zona. Photo by Sarah Luna.

For sex workers, the decision to leave la zona required a complex calculation of factors related to their intimate obligations. So few clients visited that they 
barely earned enough money to pay their rent, much less send money to their families or save for the future. Rebecca, a sex worker from Puebla who was saving her money to attend nursing school and buy a car, rhetorically asked me: "If I'm only earning enough to pay my expenses, what's the point?" Some sex workers credited their relationships with missionaries and God as factors influencing them to leave Boystown and Reynosa, and missionaries spread these stories to their Christian publics. The decisions of others to leave were sparked not only by drug violence and reduced earnings but also personal factors. Frida entered prostitution because she was coerced by and fell in love with a pimp. She continued to work after terminating that relationship to support her children. Frida eventually left la zona because she feared that her son, who was still a baby, would grow up to work for narcos or to be teased by other children for having a sex worker as a mother. Furthermore, she had a sense that her relationship with her son's father was dissolving. Sofía, who had considered leaving for years, finally took action when her teenage son, Sergio, went missing after escaping from a drug rehabilitation center in their hometown of Tampico. He had left the drug organization and had been in hiding near Mexico City for a year. When he returned to Tampico to meet his infant daughter, he was kidnapped from Sofía's house. Like many young men in Mexico, Sergio is assumed by his family to be dead, although his body has not been found. Thus, although fear of dying at the hands of narcos and a generalized anxiety were factors compelling sex workers to leave Reynosa, their intimate relationships were also profoundly affected by the increasing power of drug organizations.

Foreigners faced difficulties forging intimacies with Mexican sex workers as militarization increased tension in Reynosa. Missionaries' decisions to leave required weighing Reynosa's risks and rewards in relation to their intimate obligations to God, sex workers, children, Christian publics, and spouses. Sex workers were wary of strangers after their abuse and intimidation by armed men. Stacy, the American missionary, stopped taking short-term missionary teams into Boystown and instead had them "construct the monastery" two blocks away. However, several missionary groups canceled construction trips after seeing U.S. media depictions of Mexican violence.

Stacy was also forced to schedule an early cesarean to avoid a gun battle that was rumored to block the road to the hospital. After Stacy's daughter was born, gunfire and explosions kept the family up at night. In May 2010, Stacy and her husband abandoned their mission. While drug violence clearly factored into their decision, Stacy indicated that God told them to leave Reynosa. Team Boys- 
town had already stopped entering la zona due to increasing tensions as the Zetas and the Gulf Cartel split and fought for territory. Some of Stacy's team members told me that while before they had had "favor with the Gulf Cartel," they did not assume that the rival cartel would extend the same welcome to them. It is notable that, in Reynosa, even missionaries needed informal alliances with drug cartel representatives to carry out their work, indicating a certain alignment between God's territory and narco territory.

Police corruption further deterred American visitors. Clients reported increasing robberies and extortions by local police in Reynosa, generally, and in Boystown, particularly. Chuck, a frequent client, became hesitant to cross the border because security guards conducted revisiones, or inspections, which they used as a method to rob, extort, or blackmail clients. Several clients, as well as many Reynosa locals, believed that Boystown security guards, like the local police more generally, worked for or with narcos. Once all uniformed representatives of the state - the police, the military - could potentially represent narco power, either by disguise or collusion, power in Reynosa became reduced to the random and absolute exercise of violence through a single, undifferentiated agent of corruption. Affective atmospheres of terror extended from their temporally and spatially delimited arenas (at night, in certain neighborhoods, directed at particularly vulnerable populations) to encompass more kinds of people, places, and times of day. Anxiety and suspicion, forged in part through rumor, stymied the border's productivity. Many clients ceased to visit the prostitution zone due to fear of bodily harm, and many sex workers and missionaries chose to leave Reynosa.

\section{CONCLUSION}

Events that took place in Reynosa between 2008 and 2009 foreshadowed what would happen throughout Mexico in the following years: affective atmospheres of terror spread to more and more of the country's residents, and drug trafficking organizations penetrated social, political, and economic life in new, profoundly destructive ways. My analysis of the performativity of violent rumors draws attention to how atmospheres of terror spread through bodies. Populations terrorized by the threat of bodily harm are affected in ways collective and corporeal that shape space and change the social world.

Through the contagion of affect and the performative power of rumors about violence, narcos became posited as all-powerful, while vulnerable subjects sustained that power by circulating rumors. Eventually, most political acts — whether 
in the form of protests, local ordinances, or military action — were said by Reynosa residents to be the work of drug organizations. I have suggested that rumors of violence in an affective atmosphere of terror differ from other kinds of rumors because they cite prior acts of violence and thus reamplify the power effects of that violence. Terror is contagious in part because circulating narco-stories create intense bodily sensations that also mark a form of intimacy. The bodies of Reynosa's residents were key sites at which territory battles between soldiers and narcos were felt. These turf wars had effects on the bodies of sex workers (among others), bodies used in confrontations between narcos and soldiers. These findings offer further evidence for the value of an ethnographic approach to understanding dynamics in hostile situations like drug-war zones, where freedom of the press is compromised and survey data or brief interviews would not yield the textured data and analytic richness of long-term research.

Rumors of violence spread in such a way that even those who would have been protected by some combination of class, racial, and citizenship privileges eventually felt defenseless. Through the contagion of rumor and affect, atmospheres of terror enveloped more and more of the population. Affective shifts were in dialectical tension with real acts of torture, brutality, and murder in the world. Perhaps narcos first tested techniques of domination on the most vulnerable populations, such as Central Americans without legal status in Mexico, before applying them to the rest of the populace.

The decline of Boystown offers a case study of how drug trafficking organizations' ascendance to power and the local population's vulnerability were intensified during a period of increased militarization in the war on drugs. More than a war on crime, it constitutes a war on those who are poor, racially marked, and at the bottom of gender hierarchies. Eva once said to me, looking at the empty streets of la zona: "Vice is ending because God is mad. No clients come to visit us. We are all alone." Her comments indicate a deep feeling of abandonment, perhaps by God, the state, and clients - but missionaries and an anthropologist would eventually abandon her too. Many sex workers would also eventually leave la zona, but in the meantime, they found ways to sustain social bonds and care for one another even as they contributed to atmospheres of terror.

\footnotetext{
ABSTRACT

This article examines the effects of rumors within the Mexican and U.S. governments' militarized war on drugs. Focusing on a period during which Mexican drug organizations were strengthened and violence increased, the article follows the lives of
} 
Mexican sex workers and their clients, as well as American missionaries living in a prostitution zone in Reynosa, Tamaulipas. Borders between narco-controlled and state-controlled territory were shifted in and through the bodies of Reynosa's residents as a contagion of performative rumors came to occupy la zona. As residents told or listened to stories about torture and murder at the hands of narcos, their perceived vulnerability increased and fear came to predominate. In this article I theorize how rumors of violence shaped affective atmospheres of terror and altered spatial practices in a drug-war zone. Feelings of bodily risk first affected vulnerable populations and later spread to people who had previously felt secure in border zones. These narcostories not only circulated terror but also allowed people to achieve intimacy and maintain social bonds through the shared experience of terror. [violence; affect; performativity; rumor; militarization; Mexico; borders]

\section{NOTES}

Acknowledgments This research would not have been possible without the support of many people and institutions. First, I thank my interlocutors in Reynosa for sharing their lives with me. I extend my gratitude to the Cultural Anthropology editorial collective and the anonymous reviewers for closely and carefully reading this essay and providing such generous and constructive critique. Thank you especially to Cymene Howe for support and feedback during the final stages of the editorial process. Thank you to the colleagues, mentors, and friends who have engaged this text at various stages: Susan Gal, Julie Chu, Danilyn Rutherford, Kesha Fikes, Melissa W. Wright, Lisa Simeone, James McDonald, Alexis Salas, Maria Gonzales, Trevor Boffone, Rachel Afi Quinn, Keith McNeal, Christina Sisk, Leandra Zarnow, Sylvia Mendoza, Tshepo Masango Chery, Elizabeth Gregory, Laura-Zoë Humphreys, Abigail Rosenthal, Amanda Englert, Emily Wentzell, Roger Waldinger, Maria Islas-Lopez, Carly Schuster, Jessica Horton, Monica Mercado, Larisa Reznik, Charlotte Ashlock, Hadas Weiss, Christopher Fraga, Michelle Lelièvre, Tracey Rosen, Maurice Magaña, Michael Letteri, Danny Zborover, Kavita Singh, Nancy Postero, Veronica Pacheco, Rupert Stasch, Suzanne Brenner, John Haviland, Sergio Sanchez Diaz, Jessica Cattelino, Molly Cunningham, John Davey, Alberto DiazCayeros, Kathy Kopinak, Karina Kordova, Susana Vargas, Linda Zerilli, Robert Foster, Eleana Kim, Thomas Gibson, Daniel Reichman, and Ayala Emmett. Research and writing were supported by the National Science Foundation Graduate Research Fellowship; the Fulbright-Hays Doctoral Dissertation Abroad Fellowship; the University of Chicago Trustee's Fellowship; the University of Chicago Center for Latin American Studies Field Research Grant; the University of Chicago Lesbian and Gay Studies Project Graduate Research Grant; the Northeast Consortium Dissertation Year Visiting Diversity Fellowship in the Department of Anthropology at the University of Rochester; the James C. Hormel Dissertation Fellowship in Sexuality Studies at the University of Chicago; the Center for U.S.-Mexican Studies Predoctoral Fellowship at the School of International Relations and Pacific Studies at University of California, San Diego; the Women's, Gender and Sexuality Studies Program and the Friends of Women's Studies at the University of Houston, and the Consortium for Faculty Diversity Fellowship in the Latin American Studies Program at Davidson College.

1. I conducted fifty-seven open-ended interviews with residents of Reynosa, primarily missionaries and sex workers. I lived with missionaries for three months and with a host family for nine months. Most interviews and interactions with sex workers were conducted in Spanish, while most interviews and interactions with missionaries were conducted in English. In the interest of the privacy and security of my interlocutors, all names have been changed.

2. I have opted to use the terms "drug organization," la maña, and los narcos interchangeably, as the latter two are the terms my contacts used. In 2008 and 2009, the Gulf Cartel 
controlled the drug trade in Reynosa and had an alliance with the Zetas, but in early 2010, the two groups split and fought for territory. In 2008 and 2009, Reynosenses rarely distinguished between Gulf Cartel members and Zetas (and therefore examples used in this article follow suit).

3. Michael Taussig $(1984,464)$ notes that culture of terror is in part constituted "in the coils of rumor, gossip, story and chit-chat."

4. According to Campbell $(2009,23)$, a cartel uses bribes to gain loyalty from the military commander or head of federal police in a district. After loyalty has been purchased, soldiers and officers are used to protect storage facilities or drug lords. Further, many members of drug organizations have ties to high-ranking politicians and officials in the government and military.

5. A Reynosa police chief claimed that the military investigation of the police force was in vain, and suggested that corruption could better be found in the state police, the federal police, and the military (Roig-Franzia 2008). Twelve signs accusing government officials of protecting rival cartels were hung in public places in Reynosa and other border cities in August 2008, containing messages such as: "Mr. Calderón, if you want to stop crime, start with your corrupt cabinet” (Taylor 2008).

6. Under Calderón, the number of murders documented by the Mexican statistics agency INEGI rose from 8,867 in 2007 to 27,213 in 2011 (Molzahn, Rios, and Shirk 2013, $1)$.

7. Team Boystown did not identify as but was influenced by the New Monasticism and Emerging Church movements, which are mainly composed of young people critical of the materialism and hypocrisy of suburban evangelical churches and who seek to live among the poor like Jesus (Moll 2005; Bielo 2011).

8. Pimps were not necessary, but some women had them. Most pimps came from the Mexican state of Tlaxcala and had no connections to local drug organizations.

9. Robert Priest and Brian Howell (2013) estimate that around two million Americans participate in short-term missions each year. Churches send mission teams to border cities for a week at a time to give congregations the experience of what they term "helping the poor."

10. Lauren Berlant (2011) argues that the present is always first experienced at the level of affect.

11. I believed most of the narco-stories discussed in this article and, given my difficulty discerning between when my fear was paranoia and when it was reasonable, my avoidance of assessing the truth-value of the narratives I analyze is perhaps even more crucial.

12. Some gun battles occurred between military and drug organizations and others between rival groups. Experts have suggested that Calderón's strategy of arresting kingpins fomented succession wars within major cartels and the splintering of groups, intensifying violence on the ground (Guerrero-Gutiérrez 2011; Molzahn, Rios, and Shirk 2013).

13. Scholars of language in context would argue that this is the case with most utterances and gestures (Silverstein 1993; Hall 1999). Austin suggests that perhaps all utterances are performative, to some degree.

14. I used pseudonyms in my fieldnotes to protect the safety and privacy of my interlocutors.

15. In May 2010, 55 bodies of migrants were found in abandoned mines outside Mexico City; in July 2010, 51 corpses of migrants were found outside Monterrey (Ramsey 2011). In August 2010, 72 migrant corpses full of bullets were found in San Fernando, a town ninety miles south of Reynosa that was controlled by Zetas (Associated Press 2011). In April 2011, 145 bodies were found in mass graves. Mexican authorities arrested 16 police officers and 17 Zetas in connection with the graves (Wilkinson 2011).

16. I have since found newspaper articles speculating that these were "narco-protests" (Lacey 2009).

17. Historically, the PRI political party used similar tactics to rig elections, offering poor people money or food and a ride in exchange for a vote (Lettieri 2014).

18. In February 2009, the U.S. State Department advised Americans to avoid places asso- 
ciated with drugs and prostitution; by 2010, these became more generalized warnings to avoid whole cities and states in Mexico when several Americans were killed.

\section{REFERENCES}

Ahmed, Sara

2010 The Promise of Happiness. Durham, N.C.: Duke University Press.

Anderson, Ben

2009 “Affective Atmospheres." Emotion, Space, and Society 2, no. 2: 77-81. https:// doi.org/10.1016/j.emospa.2009.08.005.

Andreas, Peter

1995 "Free Market Reform and Drug Market Prohibition: U.S. Policies at CrossPurposes in Latin America." Third World Quarterly 16, no. 1: 75-87. https:// doi.org/10.1080/01436599550036248.

1996 “U.S.-Mexico: Open Markets, Closed Border.” Foreign Policy, no. 103: 51-69.

Associated Press https://doi.org/10.2307/1149202.

2011 "Seventy-Two Bodies at Burial Site as Mexicans Seek Missing." April 8.

Austin, J. L.

1962 How to Do Things with Words. Cambridge, Mass.: Harvard University Press.

Berlant, Lauren

2008 “Thinking about Feeling Historical." Emotion, Space, and Society 1, no. 1: 4-9. https://doi.org/10.1016/j.emospa.2008.08.006.

Bielo, James S.

2011 Cruel Optimism. Durham, N.C.: Duke University Press.

2011 Emerging Evangelicals: Faith, Modernity, and the Desire for Authenticity. New York: New York University Press.

Butler, Judith

1990 Gender Trouble: Feminism and the Subversion of Identity. New York: Routledge.

Butt, Leslie

2005 “'Lipstick Girls' and 'Fallen Women': AIDS and Conspiratorial Thinking in Papua, Indonesia.” Cultural Anthropology 20, no. 3: 412-42. https://doi.org/ $10.1525 /$ can. 2005.20.3.412.

Campbell, Howard

2009 Drug War Zone: Frontline Dispatches from the Streets of El Paso and Juárez. Austin: University of Texas Press.

2014 "Narco-Propaganda in the Mexican 'Drug War': An Anthropological Perspective.” Latin American Perspectives 41, no. 2: 60-77. https://doi.org/ $10.1177 / 0094582 X 12443519$.

Campbell, Howard, and Tobin Hansen

2014 "Is Narco-Violence in Mexico Terrorism?" Bulletin of Latin American Research 33, no. 2: 158-73. https://doi.org/10.1111/blar.12145.

Comaroff, Jean, and John L. Comaroff, eds.

2001 Millennial Capitalism and the Culture of Neoliberalism. Durham, N.C.: Duke University Press.

Crónica de Hoy

2009 "Tres horas de balacera entre militares y sicarios en Reynosa." February 18. http://www.cronica.com.mx/notas/2009/415512.html.

Curtis, James R., and Daniel D. Arreola

1991 "Zonas de Tolerancia on the Northern Mexican Border." Geographical Review 81, no. 3: 333-46. https://doi.org/10.2307/215636.

Derrida, Jacques

1982 Margins of Philosophy. Translated by Alan Bass. Chicago: University of Chicago Press. Originally published in 1972. 
Fenster, Mark

1999 Conspiracy Theories: Secrecy and Power in American Culture. Minneapolis: University of Minnesota Press.

Gould, Deborah B.

2009 Moving Politics: Emotion and ACT UP's Fight against AIDS. Chicago: University of Chicago Press.

Guerrero-Gutiérrez, Eduardo

2011 "Security, Drugs and Violence in Mexico: A Survey." Report presented at the North American Forum, Washington, DC.

Hall, Kira

1999 "Performativity." Journal of Linguistic Anthropology 9, nos. 1-2: 184-87. https:// doi.org/10.1525/jlin.1999.9.1-2.184.

Herrmann, Gretchen M.

2015 "Valuing Affect: The Centrality of Emotion, Memory, and Identity in Garage Sale Exchange.” Anthropology of Consciousness 26, no. 2: 170-81. https://doi.org/ 10.1111 /anoc. 12040 .

Heslop, Andrew

2011 "Mexico, Pakistan Most Deadly Places for Journalists in 2010." World Association of Newspapers and News Publishers website, January 14. http:// www.wan-ifra.org/articles/2011/01/14/mexico-pakistan-most-deadly-placesfor-journalists-in-2010.

Hoskins, Janet

2002 "Predatory Voyeurs: Tourists and 'Tribal Violence' in Remote Indonesia." American Ethnologist 29, no. 4: 797-828. https://doi.org/10.1525/ ae.2002.29.4.797.

Keeley, Brian L.

1999 “Of Conspiracy Theories.” Journal of Philosophy 96, no. 3: 109-26. http:// doi.org/10.2307/2564659.

Kirsch, Stuart

2002 "Rumor and Other Narratives of Political Violence in West Papua." Critique of Anthropology 22, no. 1: 53-79. https://doi.org/10.1177/0308275X020220010301.

Lacey, Marc

2009 “Drug Tie Seen to Protests in Mexico.” New York Times, February 18. http:// www.nytimes.com/2009/02/19/world/americas/19mexico.html.

Lettieri, Michael

2014 "Wheels of Government: The Alianza de Camioneros and the Political Culture of PRI Rule, 1929-1981.” PhD dissertation, University of California, San Diego. https://escholarship.org/uc/item/0026f8n5.

Lomnitz-Adler, Claudio

1995 "Ritual, Rumor, and Corruption in the Constitution of Polity in Modern Mexico." Journal of Latin American and Caribbean Anthropology 1, no. 1: 20-47.

Low, Setha M. https://doi.org/10.1525/jlca.1995.1.1.20.

2016 Spatializing Culture: The Ethnography of Space and Place. New York: Routledge. Masquelier, Adeline

2000 "Of Headhunters and Cannibals: Migrancy, Labor, and Consumption in the Mawri Imagination.” Cultural Anthropology 15, no. 1: 84-126. https://doi.org/ 10.1525/can.2000.15.1.84.

McClintock, Anne

1992 "Screwing the System: Sexwork, Race, and the Law." boundary 2 19, no. 2: 70 95. https://doi.org/10.2307/303534.

McDonald, James H.

2005 "The Narcoeconomy and Small-Town Rural Mexico." Human Organization 64, no. 2: 115-25. https://doi.org/10.17730/humo.64.2.ln16fx6k6wahxluy. 
Milenio

2010 “Turismo cayó 40 por ciento este año, dice director estatal de promoción.” August 5.

Moll, Rob

2005 “The New Monasticism.” Christianity Today, September 2. http:// www.christianitytoday.com/ct/2005/september/16.38.html.

Molzahn, Cory, Viridiana Rios, and David A. Shirk

2013 "Drug Violence in Mexico: Data and Analysis through 2012." Special report, Justice in Mexico Project. San Diego, Calif.: Trans-Border Institute. https://

Muehlmann, Shaylih justiceinmexico.org/drug-violence-in-mexico-data-and-analysis-through-2012.

2014 When I Wear My Alligator Boots: Narco-Culture in the U.S.-Mexico Borderlands. Berkeley: University of California Press.

Osborn, James

2008 “Mexico: Drug War Means an Early Night in Reynosa.” McAllen Monitor, February 9.

Pérez Arellano, Raymundo

2013 “Testimony \#1: 'We got out of Tamaulipas alive.'” Dissident Blog, March 9. https: / / www.dissidentblog.org/en/articles/testimony-1-we-got-outtamaulipas-alive.

Priest, Robert J., and Brian M. Howell

2013 "Introduction: Theme Issue on Short-Term Missions." Missiology 41, no. 2: 124 29. https://doi.org/10.1177/0091829613475744.

Proceso

2008 "Repudian abusos por operativos en Reynosa, Tamaulipas.” Editorial, January 31. http: / / www.proceso.com.mx/?p=196410.

Ramsey, Geoffrey

2011 “Video: 'Highway of Death’ Runs Past Mass Graves in Northern Mexico.” InSight Crime, April 13. http://www.insightcrime.org/news-analysis/video-highwayof-death-runs-past-mass-graves-in-northern-mexico.

Richard, Analiese, and Daromir Rudnyckyj

2009 "Economies of Affect." Journal of the Royal Anthropological Institute 15, no. 1: 5777. https://doi.org/10.1111/j.1467-9655.2008.01530.x.

Roig-Franzia, Manuel

2008 “Drug Cartels' Reign of Terror on Border.” Seattle Times, March 22. https:// www.seattletimes.com/nation-world/drug-cartels-reign-of-terror-on-border.

Rutherford, Danilyn

2012 Laughing at Leviathan: Sovereignty and Audience in West Papua. Chicago: University of Chicago Press.

Sánchez, Martín, David Carrizales, Carlos Camacho, and Raymundo León

2007 “Asesinan en Río Bravo a ex diputado y cinco acompañantes.” Jornada, November 30. http://www.jornada.unam.mx/2007/11/30/index.php?section=politica \&article $=022 \mathrm{n} 2 \mathrm{pol}$.

Silverstein, Michael

1993 "Metapragmatic Discourse and Metapragmatic Function.” In Reflexive Language: Reported Speech and Metapragmatics, edited by John A. Lucy, 33-58. New York:

Stevenson, Mark Cambridge University Press.

2010 "Eight Reporters Kidnapped in Reynosa, Press Group Says.” Brownsville Herald, March 11. http://www.brownsvilleherald.com/article_94d19cc5-eef7-5972aec5-34716e18f581.html.

Stewart, Kathleen

1999 “Conspiracy Theory's Worlds.” In Paranoia within Reason: A Casebook on Conspiracy as Explanation, edited by George E. Marcus, 13-19. Chicago: University of Chicago Press. 
2007 Ordinary Affects. Durham, N.C.: Duke University Press.

Taussig, Michael

1984 "Culture of Terror - Space of Death: Roger Casement's Putumayo Report and the Explanation of Torture." Comparative Studies in Society and History 26, no. 3: 467-97. https://doi.org/10.1017/S0010417500011105.

1986 Shamanism, Colonialism, and the Wild Man: A Study in Terror and Healing. Chicago: University of Chicago Press.

Taylor, Jared

2008 "Days after Mexican President Denounces Crime, Banners Accused Administration of Corruption.” Monitor, August 29.

Torres, Alberto

2011 “Choferes eluden la 'vía de la muerte." Universal, April 13. http:// archivo.eluniversal.com.mx/nacion/184735.html.

Vite Pérez, Miguel Ángel

2014 “Reflexiones sobre la violencia y vulnerabilidad en México." Espiral 21, no. 61: 227-58. http://www.revistascientificas.udg.mx/index.php/EspiralOculto/ article/view/270.

White, Luise

1997 "The Traffic in Heads: Bodies, Borders and the Articulation of Regional Histories." Journal of South Asian Studies 23, no. 2: 325-38. https://doi.org/ 10.1080/03057079708708540.

Wilkinson, Tracy

2011 “Mexico Mass Graves: Body Count from Mass Graves Reaches 145.” Los Angeles Times, April 15. http://articles.latimes.com/2011/apr/15/world/la-fgmexico-bodies-20110416.

Wright, Melissa W.

1999 “The Dialectics of Still Life: Murder, Women, and Maquiladoras.” Public Culture 11, no. 3: 453-73. https://doi.org/10.1215/08992363-11-3-453.

2011 "Necropolitics, Narcopolitics, and Femicide: Gendered Violence on the MexicoU.S. Border.” Signs 36, no. 3: 707-731. https://doi.org/10.1086/657496.

Yeh, Rihan

2012 “Two Publics in a Mexican Border City." Cultural Anthropology 27, no. 4: 71334. https://doi.org/10.1111/j.1548-1360.2012.01168.x. 